\title{
Risk Factors of Stunting in Children Aged 6-59 Months: ACase-Control Study in Horticulture Area
}

\author{
Prayudhy Yushananta* (D), Mei Ahyanti(D) \\ Department of Environmetal Health, Tanjungkarang Health Polytechnic, Lampung, Indonesia
}

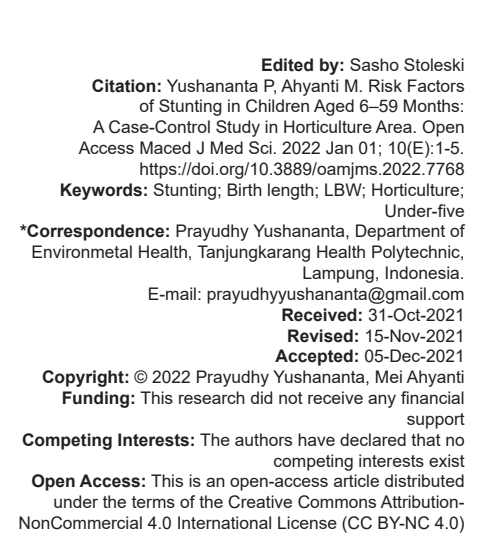

Introduction

Malnutrition is a critical public health problem for children under five in developing countries, including Indonesia. Malnutrition is due to many interrelated factors and has detrimental health effects in the short and long term [1], [2]. Malnutrition will affect children's cognitive and physical development, increase the risk of infection, and significantly contribute to child morbidity and mortality [3], [4], [5], [6]. The high indicators of malnutrition in a country reflect children's low nutritional status and health under five [2], [7]. Three extensively recognized indicators of children's nutritional status are stunting, wasting, and underweight, and stunting indicates chronic malnutrition form [1], [2], [6], [8], [9], [10], [11]. A stunted child if their height for age is over two standard deviations below the median of the World Health Organization (WHO) 2005 [2], [12].

Stunting is the best measure of malnutrition in childhood, a predictor for long-term morbidity and mortality, and long-term societal costs [13]. Children who suffer from stunting will grow into adults at risk of obesity, glucose tolerance, coronary heart disease, hypertension, osteoporosis, decreased performance, and productivity [2], [5], [6], [10], [11], [13], [14].

Globally, in 2025, malnutrition contributes to at least half of all deaths each year in children under five [7], [13], [15]. In 2025, estimating 127 million will be stunted [16]. Prevalence was greater in developing countries, especially in South Asia and Africa [15], [16], [17]. In Indonesia, the stunting prevalence was $30.8 \%$, consisting of $11.5 \%$ very short and $19.3 \%$ short.

Many factors are associated with stunting. Several studies reported socioeconomic inequality, geographic differences, practices of feeding, food insecurity, education, and childhood morbidity, infection, and environmental [3], [4], [5], [6], [11], [18]. Stunting is also associated with micronutrient deficiencies, such as protein, iron, zinc, calcium, and vitamins $D, A$, and $C$ [15]. There are limited research reports on risk factors for stunting, especially in horticultural farming areas. In the study area (Liwa City), the risk factors for stunting in children aged 24-59 months have not been studied. It is crucial to identify risk factors for stunting to overcome the problem of stunting and its consequences. The study aimed to identify risk factors for stunting among children under five in the horticultural areas. 


\section{Materials and Methods}

\section{Study design and setting}

A case-control study was conducted in Liwa City, West Lampung Regency, to compare previous exposures between stunted children (cases) and nonstunting children (controls). Seven horticultural farming villages were selected from the twelve villages in the city. This research was conducted after obtaining approval from the Health Research Ethics Committee, Tanjungkarang Health Polytechnic (No.261/KEPKTJK/V/2020). Permission from the West Lampung District Health Office and the Liwa Community Health Center was obtained. Guided by the Helsinki protocol, informed consent was taken, and data handling was confidential. No risk of harm would be to the participants, and participants have the right to withdraw during the study. All study procedures were described before the interview. Nutrition education for children was given after the interview.

\section{Study period and study participants}

The study was conducted from July to August 2020. Children aged 12-59 months with a mother or caregiver who lived for at least 6 months in the study area were included in the study. Children without mothers or caregivers, children who appeared to have physical disabilities, children whose exact age was unknown were excluded from the study. Cases were children with stunting (high $\mathrm{z}$ score for age $<-2 \mathrm{z}$ score). Controls were children who were not stunting (high $z$ score for age $\geq-2 z$ score), selected from the case's nearby neighbor who was of the same age. If multiple controls are found, they are randomly selected. formula:

The sample size calculated was following

$$
n=\frac{2^{\circ} \bar{p}^{\infty} \bar{q}^{\infty}\left(Z_{\alpha}+Z_{\beta}\right)^{2}}{\left(p_{1}-p_{0}\right)^{2}}
$$

where, $\mathrm{n}=$ sample size of case; = mean proportion exposed in the case and control group; $Z_{\alpha}=$ spcifield power; $Z_{\beta}=$ specifield significance; $p_{1}=$ proportion exposed in the case group; $p_{0}=$ proportion exposed in the control group.

The exposure considered was parenting (32.9\%). Assuming $95 \% \mathrm{Cl}, 90 \%$ power, control to case ratio $3: 1$, the total sample size is 160 (120 controls dan 40 cases).

\section{Data collection and procedures}

Data were collected from measurements and interviews using a questionnaire. All samples of children under five were measured in height with WHO standard measurements. The standard reclining board is used to measure the children aged $<24$ months in the supine position. The children aged 24-59 months are measured in a standing position. History of birth length, birth weight, immunization are asked for and validated with records from the official at KMS (Health Toward Book). All mothers or caregivers were asked for their education and occupation. Parenting is a mother's behavior in caring for her child. The 24-h diet recall method was used to assess children's diets using a checklist adapted from WHO guidelines.

\section{Data analysis}

Data were entered into SPSS (24.0) after being checked for completeness, edited, coded. Code outcomes were given, 1 for cases and 0 for controls. Data entered for analysis were mother's education, mother's labor status, birth length, birth weight, immunization, protein intake, parenting, and sanitation access. The bivariate analysis used the $\chi^{2}$ statistic to measure the variables associated with outcome (stunted). The calculation of Crude OR and $\mathrm{Cl}=95 \%$ was also carried out. Variables with a $p<0.25$ were transferred to a multivariate analysis to identify risk factors. To determine the relationship between risk factors and stunting, we used multiple logistic regression analysis. For all statistical tests, $p \leq 0.05$ was considered significant. The Hosmer and Lemeshow test was applied to test the fit model of the multiple logistic regression.

\section{Results}

\section{Sociodemographic and economic characteristics of participants}

A total of 160 (120 controls and 40 cases) children aged 6-59 months and their mothers or caregivers participated in the study. Nobody dropped out during the study period, so the participation rate was $100 \%$. The number of samples was boys and girls almost equal (Table 1), but most were in the 6-23 month age group $(73.13 \%)$. The majority of mothers or

Table 1: Socio-demographic characteristics

\begin{tabular}{|c|c|c|c|}
\hline \multirow[t]{2}{*}{ Variables } & Case (\%) & Control (\%) & \multirow[t]{2}{*}{$\mathrm{p}$-value } \\
\hline & $(n=40)$ & $(n=120)$ & \\
\hline \multicolumn{4}{|l|}{ Sex of child } \\
\hline Female & $22(55.0)$ & $54(45.0)$ & \multirow[t]{2}{*}{0.361} \\
\hline Male & $18(45.0)$ & $66(55.0)$ & \\
\hline \multicolumn{4}{|c|}{ Age of children (months) } \\
\hline $6-23$ & 29 (73.5) & $88(73.3)$ & \multirow[t]{2}{*}{1.000} \\
\hline $24-59$ & $11(27.5)$ & $32(26.7)$ & \\
\hline \multicolumn{4}{|l|}{ Family's income } \\
\hline Low & 35 (87.5) & 95 (79.2) & \multirow[t]{2}{*}{0.350} \\
\hline Medium to high & $5(12.5)$ & $25(20.8)$ & \\
\hline \multicolumn{4}{|c|}{ Mother's level education } \\
\hline Low & $18(45.0)$ & $28(23.3)$ & \multirow[t]{2}{*}{0.02} \\
\hline High & $22(55.0)$ & $92(76.7)$ & \\
\hline \multicolumn{4}{|c|}{ Mother's labor status } \\
\hline Work & $17(42.5)$ & $47(39.2)$ & \multirow[t]{2}{*}{0.85} \\
\hline Not work & $23(57.5)$ & $73(60.8)$ & \\
\hline
\end{tabular}


caregivers have completed junior high school (71.25\%), but they do not work $(60.0 \%)$, and the family income is low (81.25\%).

\section{Health and child feeding-related characteristics of participants}

Although the majority was normal (Table 2), about $19(47.5 \%)$ of children in the case group and $4(3.3 \%)$ in the control group were born stunted. There were also $13(32.5 \%)$ children in the case group and $9(7.5 \%)$ in the control group born with low birth weight. Complete immunization was obtained by about $36(90.0 \%)$ children in the case group and $92(76.7 \%)$ in the control group. Almost all $(90.63 \%)$ children in the case and control groups received adequate protein intake. However, around $24(60 \%)$ in the case group and $59(49.2 \%)$ lacked parenting.

Table 2: Health and child feeding characteristics

\begin{tabular}{|c|c|c|c|}
\hline \multirow[t]{2}{*}{ Variables } & Case $(n=40)$ & Control $(n=120)$ & \multirow[t]{2}{*}{$p$-value } \\
\hline & Number (\%) & Number (\%) & \\
\hline \multicolumn{4}{|l|}{ Birth length } \\
\hline Low & $19(47,5)$ & $4(3.3)$ & \multirow[t]{2}{*}{$<0.01$} \\
\hline Normal & $21(52.5)$ & 116 (96.7) & \\
\hline \multicolumn{4}{|l|}{ Birth weight } \\
\hline Low & $13(32.5)$ & $9(7.5)$ & \multirow[t]{2}{*}{$<0.01$} \\
\hline Normal & 27 (67.5) & $111(92.5)$ & \\
\hline \multicolumn{4}{|l|}{ Immunization } \\
\hline Incomplete & $4(10.0)$ & $28(23.3)$ & \multirow[t]{2}{*}{0.110} \\
\hline Complete & $36(90.0)$ & 92 (76.7) & \\
\hline \multicolumn{4}{|l|}{ Protein intake } \\
\hline Low & $10(25.0)$ & $5(4.2)$ & \multirow[t]{2}{*}{$<0.01$} \\
\hline Adequate & $30(75.0)$ & 115 (95.8) & \\
\hline \multicolumn{4}{|l|}{ Parenting } \\
\hline Lack & $24(60.0)$ & $59(49.2)$ & \multirow[t]{2}{*}{0.315} \\
\hline Normal & $16(40.0)$ & $61(50.8)$ & \\
\hline
\end{tabular}

\section{participants \\ Environmental related characteristics of}

Almost all children in the case group (95.0\%) and the control group (97.5\%) were found in homes with access to safe drinking water. However, about $7(17.5 \%)$ children in the case group and $4(3.3 \%)$ in the control group were found in homes without access to healthy sanitation, as Table 3 .

Table 3: Environmental characteristic

\begin{tabular}{|c|c|c|c|}
\hline \multirow[t]{2}{*}{ Variables } & Case $(n=40)$ & Control $(n=120)$ & \multirow[t]{2}{*}{$p$-value } \\
\hline & Number (\%) & Number (\%) & \\
\hline \multicolumn{4}{|c|}{ Access to drinking water } \\
\hline No-access & $2(5.0)$ & $3(2.5)$ & \multirow[t]{2}{*}{0.793} \\
\hline Access & $38(95.0)$ & $117(97.5)$ & \\
\hline \multicolumn{4}{|c|}{ Access to sanitation } \\
\hline No-access & $7(17.5)$ & $4(3.3)$ & \multirow[t]{2}{*}{0.007} \\
\hline Access & $33(82.5)$ & $116(96.7)$ & \\
\hline
\end{tabular}

\section{Risk factors of stunting}

Only 4 of the 12 variables associated with stunting $(p<0.05)$ were shown from multiple logistic regression analysis (Table 4). The fit model is shown by the Homers and Lemeshow test obtained $(p=0.253)$. All variables with a $p<0.25$ from the bivariate analysis were entered into the model in this work. They are the mother's education, birth length, birth weight, immunization, protein intake, parenting, and sanitation access. Then they are issued one by one following the largest $p$-value. Interaction tests were also carried out, but none of them showed interactions between variables.

Table 4: Risk factor for stunting

\begin{tabular}{|c|c|c|c|c|}
\hline Variables & $\begin{array}{l}\begin{array}{l}\text { Case } \\
(\mathrm{n}=40)\end{array} \\
\begin{array}{l}\text { Number } \\
(\%)\end{array} \\
\end{array}$ & $\begin{array}{l}\begin{array}{l}\text { Control } \\
(\mathrm{n}=120)\end{array} \\
\text { Number } \\
(\%)\end{array}$ & $\begin{array}{c}\text { Crude OR } \\
(95 \% \mathrm{Cl})\end{array}$ & $\begin{array}{l}\text { Adjusted OR } \\
(95 \% \mathrm{Cl})\end{array}$ \\
\hline \multicolumn{5}{|l|}{ Birth length } \\
\hline Low & $19(47.5)$ & $4(3.3)$ & $26.24(8.11-84.89)$ & $17.57(5.02-61.51)$ \\
\hline Normal & $21(52.5)$ & $116(96.7)$ & 1 & 1 \\
\hline \multicolumn{5}{|l|}{ Birth weight } \\
\hline Low & $13(32.5)$ & $9(7.5)$ & $5.94(2.30-15.33)$ & $4.35(1.38-13.78)$ \\
\hline Normal & $27(67.5)$ & $111(92.5)$ & 1 & 1 \\
\hline \multicolumn{5}{|l|}{ Protein intake } \\
\hline Low & $10(25.0)$ & $5(4.2)$ & $7.67(2.43-24.12)$ & $4.96(1.22-20.26)$ \\
\hline $\begin{array}{l}\text { Adequate } \\
\text { Access to } \\
\text { sanitation }\end{array}$ & $30(75.0)$ & $115(95.8)$ & 1 & 1 \\
\hline No-access & $7(17.5)$ & $4(3.3)$ & $6.15(1.69-22.3)$ & $6.06(1.25-29.35)$ \\
\hline Access & $33(82.5)$ & $116(96.7)$ & 1 & 1 \\
\hline
\end{tabular}

The proportion of children born shortly was significantly higher in the case group than in the control group. Low birth length (boys $<46.1 \mathrm{~cm}$, and girls $<45.6 \mathrm{~cm})$ was found to be a risk factor for stunting (adjusted odds ratio $[\mathrm{AOR}]=17.57 ; 95 \%$ confident interval [Cl]: 5.02-61.51). Birth weight $<2500$ grams was also a risk factor for stunting $(\mathrm{AOR}=4.35 ; 95 \% \mathrm{Cl}$ : 1.38-13.78). The proportion of children with low protein intake was higher in the case group than in the control group (AOR $=4.96 ; 95 \% \mathrm{Cl}: 1.22-20.26$ ). We also found a statistically significant relationship between house access to sanitation and stunting (AOR $=6.06 ; 95 \%$ $\mathrm{Cl}$ : 1.25-29.35). This study found that the dominant variable related to stunting was the low birth length.

\section{Discussion}

Of all the factors studied, the length of birth showed the dominant risk factor for stunting in horticulture farming areas. The results confirm Islam, that low birth length and low birth weight are relationships with stunting [17]. Birth length is associated with low maternal nutritional intake during pregnancy, which is influenced by low family economic status [2], [15], and food insecurity in the family [19].

Food insecurity in the family results in a decrease in the variety and the nutritional value of food consumed. It will sustainably affect the family's nutritional status, including child development. In pregnant women, which affect stunted babies' birth [20], [21]. Access and availability of food for the poor combine poverty problems, lack of permanent jobs, low and irregular cash income, and limited purchasing power [19], [21], and are closely related to low education levels [22].

Besides impaired motor and verbal development, an increase in degenerative diseases, morbidity, and mortality, a further concern of stunting is 
the disruption of cognitive development [2], [5], [6]. Most children with early malnutrition did not finish high school and work as manual laborers [20]. Impaired cognitive development and learning achievement will reduce work productivity to hinder economic growth, increase poverty, and widen inequality in a country [20], [23].

Multivariate analysis showed that four variables were significantly associated with the incidence of stunting. If related to the child's life span, it has caused the mother's nutritional status during pregnancy. These results explain the concept of stunting in the first 1000 days of life [15], [16], [17], [24]. The role of mothers is critical in facilitating interventions through strengthening their nutritional status during pregnancy and breastfeeding [24].

Malnutrition in pregnancy results from a low average intake of protein, fat, total energy, and often insufficient micronutrients such as folate, $\mathrm{Fe}, \mathrm{Ca}$, and $\mathrm{Zn}$. Malnutrition in pregnant women affects disruption of intra-uterine growth [24] due to LBW, stuntedness, perinatal mortality [4], [7], [22], [25]. Linear growth failure is mostly caused in the intra-uterine period due to an inadequate diet [13].

Malnutrition in pregnancy is detected from anemia [15]. Anemia is a condition characterized by an abnormal decrease in the total mass of red blood cells caused by blood loss due to acute or chronic bleeding, destruction of red blood cells, and insufficient red blood cell production. Anemia is a risk for pregnant women in agricultural areas due to the chronic impact of pesticide exposure [26]. Sanitation access is associated with increased exposure to microbes and infectious diseases, especially diarrhea [1], [9]. Fecaloral pathways are water, food, vectors, and vectors [27].

Control with a nutrition approach for the first 1,000 days by promoting healthy behaviors, breastfeeding, nutrition during pregnancy includes micronutrient supplementation, breastfeeding, and disease prevention will reduce child malnutrition, especially chronic malnutrition in the form of stunting [15], [24]. Nutrition-sensitive interventions must also highlight a fundamentally important factor that indirectly impacts mothers' and children's nutrition, namely women's empowerment. Women's empowerment is a process of improving women's institutions and status. It will affect household access to resources, including allocations for children's health and nutrition.

\section{Conclusions}

This study found four factors associated with stunting among children aged 6-59 months in horticulture farming areas, length at birth, LBW, protein intake, and access sanitation. Of the four variables, it indicates malnutrition during pregnancy. Therefore, it needs intervention and nutrition programs for pregnant women, including micronutrient supplementation. It also empowers women in the family to affect household access to resources, including allocations for children's health and nutrition.

\section{Author Contributions}

All the authors contributed equally to the preparation, development, and completion of this manuscript.

\section{Ethics}

This article is original and contains unpublished material. The corresponding author confirms that the other authors have read and approved the manuscript and that there were no ethical issues involved.

\section{References}

1. Bomela NJ. Social, economic, health and environmenta determinants of child nutritional status in three central Asian republics. Public Health Nutr. 2009;12(10):1871-7. https://doi. org/10.1017/S1368980009004790

PMid:19232149

2. World Health Organization. Guideline: Updates on the Management of Severe Acute Malnutrition. Geneva, Switzerland: World Health Organization; 2013. p. 1-115.

3. Imelda I, Rahman N, Nur R. Risk factors for stunting in children aged 2-5 years at biromaru health center. J Nutr Health. 2020;2(1):39-43.

4. Rahman FD. The effect of feeding patterns on the incidence of stunting in toddlers. Indones J Health Sci. 2018;10(1):15-24.

5. Adedeji I, John C, Okolo S, Ebonyi A, Abdu H, Bashir M. Malnutrition and the intelligence quotient of primary school pupils in Jos, Nigeria. Br J Med Med Res. 2017;21(2):1-13. https://doi.org/10.9734/BJMMR/2017/32504

6. He P, Liu L, Salas JM, Guo C, Cheng Y, Chen G, et al. Prenatal malnutrition and adult cognitive impairment: A natural experiment from the 1959-1961 Chinese famine. Br J Nutr. 2018;120(2):198203. https://doi.org/10.1017/S0007114518000958 PMid:29720288

7. Atmarita. Optimal nutritional intake to prevent stunting. Health Data Inf Bull. 2018;1:14-25.

8. Khan S, Zaheer S, Safdar NF. Determinants of stunting, underweight and wasting among children $<5$ years of age: Evidence from 2012-2013 Pakistan demographic and health survey. BMC Public Health. 2019;19(1):358. https://doi. org/10.1186/s12889-019-6688-2

PMid:30935382 
9. Karpati J, Neubourg C, Laillou A, Poirot E. Improving children's nutritional status in Cambodia: Multidimensional poverty and early integrated interventions. Matern Child Nutr. 2020;16(Suppl 2):e12731. https://doi.org/10.1111/mcn.12731 PMid:32621576

10. Kang Y, Aguayo VM, Campbell RK, Dzed L, Joshi V, Waid JL, et al. Nutritional status and risk factors for stunting in preschool children in Bhutan. Matern Child Nutr. 2018;14(Suppl 4):e12653. https://doi.org/10.1111/mcn.12653

PMid:30412341

11. Semba RD, de Pee S, Sun K, Sari M, Akhter N, Bloem MW. Effect of parental formal education on risk of child stunting in Indonesia and Bangladesh:Across-sectional study. Lancet. 2008;371(9609):3228. https://doi.org/10.1016/S0140-6736(08)60169-5 PMid:18294999

12. Ministry of Health Indonesia. Decree of the Minister of Health of the Republic of Indonesia Number 1995/Menkes/SK/ XII/2010 Concerning Anthropometric Standards for Assessing the Nutritional Status of Children. Ministry of Health Indonesia, 1995/Menkes/SK/XII/2010 Indonesia. Ministry of Health Indonesia; 2010.

13. Victora CG, Adair L, Fall C, Hallal PC, Martorell R, Richter L, et al. Maternal and child undernutrition: Consequences for adult health and human capital. Lancet 2008;371(9609):340-57. https://doi.org/10.1016/S0140-6736(07)61692-4 PMid:18206223

14. Berkes J, Raikes A, Bouguen A, Filmer D. Joint roles of parenting and nutritional status for child development: Evidence from rural Cambodia. Dev Sci. 2019;22(5):e12874. https://doi.org/10.1111/ desc. 12874

PMid:31148355

15. Ministry of Health Indonesia. The Situation of Stunting in Indonesia. Health Data and Information Bulletin. Ministry of Health Indonesia. 2018;1: p. 6-18.

16. World Health Organization. Stunting Global and Regional Trends Jme-(unicef-who-wb). Geneva: World Health Organization; 2020. Available from: https://www.who.int/data/gho/data/ themes/topics/indicator-groups/indicator-group-details/GHO/ gho-jme-global-and-regional-trends-stunting-jme-unicefwho-wb. [Last accessed on 2020 Dec 02].

17. Islam MS, Ullah AN, Mainali S, Imam MA, Hasan MI. Determinants of stunting during the first 1,000 days of life in Bangladesh: A review. Food Sci Nutr. 2020;8(9):4685-95. https://doi.org/10.1002/fsn3.1795

PMid:32994930

18. Yushananta $P$, Ahyanti M, Anggraini $Y$. Risk of pesticides on anaemia events in horticulture farmers. Int $\mathrm{J}$ Innov Creativ Change. 2020;13(2):30-40.

19. National Development Planning Agency. National Action Plan for Food and Nutrition 2011-2015; 2011. p. 1-86. Available from: https://www.bappenas.go.id/files/4613/5228/2360/ ran-pg-2011-2015.pdf. [Last accessed on 2020 Dec 02].

20. Galler JR, Bryce C, Waber DP, Zichlin ML, Fitzmaurice GM, Eaglesfield D. Socioeconomic outcomes in adults malnourished in the first year of life: A 40-year study. Pediatrics. 2012;130(1):e1-7. https://doi.org/10.1542/peds.2012-0073 PMid:22732170

21. Kusumawati E, Rahardjo S, Sari HP. Model for controlling risk factors for stunting in children under three years. Natl Public Health J. 2015;9(3):249.

22. Azwar A. Trends in Nutrition Problems and Challenges in the Future. Ministry of Health; 2004. p. 1-16.

23. Waber DP, Bryce CP, Girard JM, Zichlin M, Fitzmaurice GM, Galler JR. Impaired IQ and academic skills in adults who experienced moderate to severe infantile malnutrition: A 40-year study. Nutr Neurosci. 2014;17(2):58-64. https://doi.org/10.1179/ 1476830513Y.0000000061

PMid:23484464

24. Kinshella ML, Moore SE, Elango R. The missing focus on women's health in the First 1,000 Days approach to nutrition. Public Health Nutr. 2021;24(6):1526-30. https://doi.org/10.1017/ S1368980020003894 PMid:33023698

25. World Health Organization. Childhood Stunting: Context, Causes and Consequences WHO Conceptual Framework. $9^{\text {th }}$ ed. Geneva: World Health Organization; 2013.

26. Petit C, Chevrier C, Durand G, Monfort C, Rouget F, Garlantezec R, et al. Impact on fetal growth of prenatal exposure to pesticides due to agricultural activities: A prospective cohort study in Brittany, France. Environ Health. 2010;9(1):71.

27. Pickering AJ, Ercumen A, Arnold BF, Kwong LH, Parvez SM, Alam $M$, et al. Fecal indicator bacteria along multiple environmental transmission pathways (water, Hands, food, soil, flies) and subsequent child diarrhea in Rural Bangladesh. Environ Sci Technol. 2018;52(14):7928-36.

PMid:29902374 